\title{
SECTION II.
}

\section{ENGINEERING AND ARCHITECTURE.}

\section{ADDRESS}

By Henry Join Marten, M.Inst.C.E.

PRESIDENT OF TIIE SECTION.

\section{INTRODUCTORY.}

TeE subjects for consideration in this section - namely, Engineering and Architecture-although necessarily limited to their sanitary aspects only, cover a wide area, and present numerous and important fentures, each of which would be more than sufficient for the text of an arddress.

For instance, the works in connection with fen drainage, town and village sewerage, house drainage and domestic sanitation, water supplies and fittings, luminants in their sanitary aspects, building materials and methods of house construction, warming and ventilation, smoke abatement, and many other matters too numerous to mention, are all included witlin the limits assigned to this section, and you will probably have the opportunity of discussing some of them.

Although considering the extent of our information, and the light we now have with respect to sanitary matters, and the extent also of our opportunities, we have not much reason to boast of the progress we have made as a nation in practical sanitation, compared with what we might have made during the past 40 years; yet it may be permissible-in fact, it may be advantageous - to take a retrospect of some of the advances made during that period, and I invite you to do so with me fur a short space of time. 


\section{Fen Drainage.}

Amongst the subjects which I have named in my introductory remarks as within the range of those referred to us is that of fen drainage.

The sanitary influences of the works carried out in this department of engineering have, I think, been much overlooked, as those sanitary influences have been incidental only to the main objects of fen drainage works, which have been principally directed to the improvement of fen and marsh lands for pasture and other agricultural purposes.

From a sanitary point of view, this subject of fen drainage may not at first sight appear to be a large one, but considering that in the fen counties of Lincoln, Huntingdon, Bedford, and Cambridge there is a population of 850,000 persons, it is certainly worthy of attention.

During the past 40 years grcat improvements have taken place in this department of sanitary work.

The old windmill, with its irregular, inadequate, ancl imperfectly applied power, has given way to greatly improved pumping machinery actuated by steam, by which means the line of saturation has been kept at a much lower level than formerly was possible over large tracts of fen country.

The total quantity of land which has to be kept dry by pumping in the valleys of the Ouse, the Nene, the Welland, and the Witham rivers is about 455,000 acres. That acrenge is equal to about 700 square miles, or equal nearly to the whole area of Worcestershire; and to show the improvements which have been effected in some parts of these fens, I find it stated in a paper by $\mathrm{Mr}$. Lawrence Gibbs, which appears in Vol. XCIV., Part IV., of the Minutes of Proceedings of the Institution of Civil Enginecrs, that two fens, viz., Deeping Fen in the Welland Valley, and Littlepool and Downham Fen in the Ouse Valley, having together an area of nearly 60,000 acres, which were formerly kept "in a half-cultivated state" by means of 119 windmills, are now effectually clrained by means of four steam engines.

The lowering of the line of saturation, or, in other words, the lowering of the underground water level effected by these improrements, has a most important bearing on the sanitary condition of those fen districts.

When the level or line of saturation is higher than the point below the surface of the ground which is affected by the heat of the sum, or when the level is within capillary range of the surface, large volumes of miasmatic vapours are occasionally 
given off, which spread their depressing influences far and wide over the fen country.

When, on the other hand, the line of saturation is drawn down below the points named, the evolution of miasmatic vapours is greatly reduced; and with their disappearance, numerous forms of febrile and rheumatic complaints cease to exist.

Great sanitary advantages have resulted also from "The Land Drainage Act of 1861," in accordance with the provisions of which numerous Drainage Boards have been constituterl under the authority of "The Land Commissioners for England," whose cluties have now been transferred to the recently constituted "Board of Agriculture."

By their favour, I have been furnished with the information, tabulated below, which shows the wide areas over which the beneficial influence of the Land Drainage Act has been extended since it came into operation twenty-eight years ago.

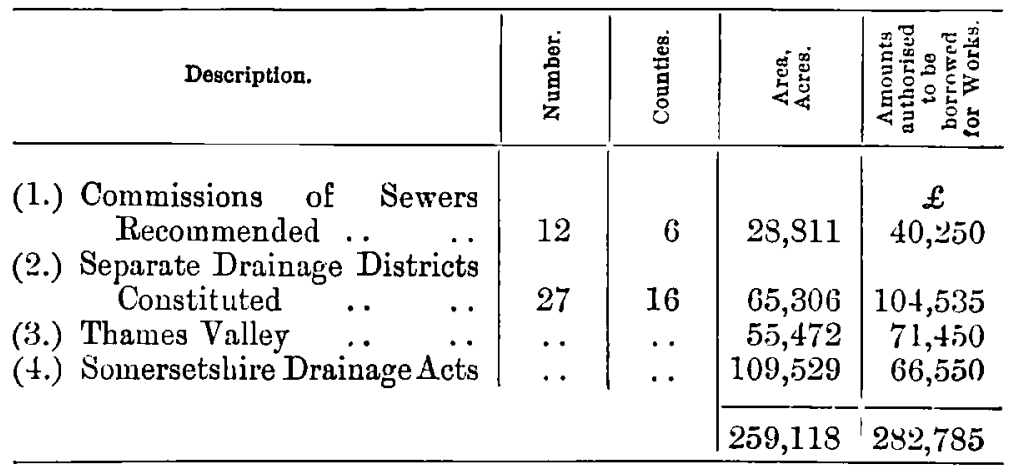

It will be seen, therefore, that " the Land Commissioners for England" have incidentally contributed to the amelioration of the sanitary condition of the inhabitants residing on no less than a quarter of a million of acres, or 400 square miles of country, by the constitution of numerous drainage districts, and by authorising an expenditure for carrying out carefully considered schemes for main drainage and other such works of more than a quarter of a million sterling. I say carcfully considered schemes, because as one of their engineering advisers, I know how minutely every point is considered before any drainage district is constituted and before any works are authorised by the Isand Commissioners.

The main drains of many old districts have also been greatly improved, by the lowering of the outfalls.

In one case, that of the Grand Sluice at Boston, the sill of 
the new and enlarged sluice has been lowered 3 feet and the seaward chamnel 8 feet, thereby practically raising the level of 500,000 acres, or 800 square miles of fen-land considerably abore the previous line of saturation.

There is no doubt that these great improvements have materially raised the sanitary status of all such districts, and have done much to minimise the physical disadvantages of fen-life.

In proof of this, Dr. Farr, in his "Vital Statistics" (pages 136 and 137) states, "The great land drainage works have had great influence in improving the health of the inhabitants of the Isle of Ely, as by their means the atmosphere has been purified and dried."

Agrain the same authority states that at Orsett, near Tilbury, in Essex, a remarkable reduction in the cleath-rate has occurred during the thirty years, 1841 to 1870 , "partly due to sanitary improvements, but mainly to the drainage of the land and consequent dryness of the soil."

He also states that, in three fen districts in Cambridgeshire, namely, North Witchford, Whittlesea, and Wisbeach, containing an aggregate population of between 50 and 60 thousand persons, the death-rate, in the thirty years between 1841 and 1870 , has been reduced from $25 \frac{2}{3}$ to $20 \frac{1}{3}$ per thousand, or nearly 20 per cent.

He also states that in Wisbeach, the deaths from phthisis were reduced from 2 per thousand in the ten years, 1851-60, to 1.6 per thousand in the ten years, from 1861 to 1870 -or 20 per cent.; whilst at Orsett deaths from the same cause were reduced in the same periods, from 2.8 to 1.9 per thousand, or 32 per cent.

\section{Town, Village, and House Drainage.}

Passing from the subject of fen drainage, I now propose to make a few remarks on the improvements which have been effected, during the past forty years, in town, village, and house drainage.

I remember the early reports of the Sanitary Inspectors of what was then termed the Buard of Health, as to the state of things forty years since, with regard to these subjects.

The reports disclosed, as then almost universally existing, a most horrible state of affairs, which is now, happily, only exceptional.

Open and almost stagnant sewers in close proximity either to the front or back doors of rows of houses, and, whilst festering there, giving off large volumes of poisonous gases. 
Leaky dumb-wells, sunk in porous ground, receiving the sewage from large numbers of houses, with the pumps for the supply of the said houses drawing their water from shallow wells sunk in close proximity to those dumb-wells.

Drains, where they did exist, untrapped, and through which at night, when all the donrs and windows in the houses were closed, the only supply of air for the inmates conld be obtained.

Sewers, properly described as only "elongated cesspools," much too large for the work to be performed, constructed in many cases of porous materials, of very unscientific section, and with but little regard to gradient.

No one whose memory does not carry him back to that periorl, can now conceive of the amount of ignorant and selfish opposition, which Mr. (now Sir Edwin Chadwick, K.C.B.) encountered, when, acting as Secretary to the Board of Health of that period, it became his duty to call public attention to this state of things, and to sugrgest the remedies for them.

Obloquy was thrown upon everything he said or did in connection with sanitary matters. The facts as to the existing sanitary abominations which he had carefully collected and marshalled, were either boldly denied, or defended as at least necessary evils. Every vested interest, from the nightit-soil man to high municipal functionaries, was against him, and had he not been as patient as $J_{o b}$, and as callous to adverse criticism as the pachydermatous monster, described in the poem of which that patriarch is the hero, was to spears and arrows, he could not have accomplished the great sanitary revolution which has been his life work, and to which this generation is so much indebted.

I had the pleasure of making his acquaintance during the period when he was battling for sanitary reform against all these adverse influences, and I feel it one of the greatest honours of my life that the friendship then commenced has been continued up to the present time without break or interruption.

One of the great difficulties with which Sir Edwin Chadwick had to contend was the then existing idea that every sewer must be a "Cloaca Maxima."

Classical gentlemen when visiting Rome were shown that sewer amongst the other antiquities of the place, and being in the humour to fall down and worship any work of the imperial and practical Romans, they, of course, fell down and worshipped that particular work, which was all very well in its place, but which was not adapted for the universal and indiscriminate application which they made of it.

If this worship had been in the nature of a "silent culte" it would probably have done very little harm, but, unfortunately, 
the worshippers were zealous to make proselytes, and everywhere preached the doctrine of large sewers-" nothing smaller than such as a full-grown man could walk upright in,"-and, in fact, everywhere and for all sewage purposes, "Cloaca Maxima, Cloaca Maxima," was the cry.

Proselytes were, of course, soon made amongst the classical architects who had copied the buildings and smelt all the unsavoury odours of Rome, which ought not to have existed had "Cloaca Maxima" been all that highly poetic fancy had painted it; and when they returned to England and received commissions to build or re-build some of the stately mansions of our country gentlemen, they commenced operations by making large cavernous "Cloaca Maxime" under and about the foundations-casily satisfying their clients that all was perfection by reminding them of their early studies, and of the great name and glory of the "Cloaca Maxima;" with the unhappy consequence, that, for some then inexplicable cause, notwithstanding situation and every advantage of pure air and good water supply, the dwellers in the finished mansion were always victims to some form of the numerous complaints which we now know to be due to the presence of "sewer gats."

To show that I am not exagrerating, I may state that not long since I had to inspect a nobleman's house in one of the midland counties, which only 30 years since had been sewered by a leading London architect on the "Cloaca Maxima" principle. Within the last two or three years the louse in question had become almost uninhabitable on account of the presence of sewer gas, traceable to these large sewers; and besides the health of the in-dwellers, a rental of several hundred pounds per annum, was placed in jeopardy.

This led to the doing away with the old-fashioned "Cloaca Maxima" under the building, and the introduction of the modern small pipe sewer and fittings, and the house is now free from that insidious gnest-sewer gas.

I have mentioned the part taken by architects in the spread of "Cloaca Maxima" worship, and lest they should deem me unfair in singling them out, I am about to confess that engincers, after almiring the bridges, roads, and aqueducts of the old Romans in all parts of their empire, and especially the splendid remains of those works in Italy, were, like the architects, also smitten with the same unhappy disease of "Cloaca Maxima" worship.

It is needless to say that builders and contractors saw no reason to quarrel with "Cloaca Maxima" specifications which made domestic sewerage works " jobs worth doing."

Shortly after the advent of Sir Edwin Chadwick, however, 
"Cloaca Maxima" worship received more of that gentleman's attention than its worshippers altogether appreciated; and after being severely wounded in several vulnerable points by that veteran sanitarian, this form of worship was, after a severe struggle, finally and ignominiously done to death in, I believe, a backyard in Westminster.

The way of it was this. Some practical but scientific sceptics one day took a peep into one of the old-fashioned metropolitan "Cloace Maximie."

To their astonishment they found more than four-fifths of the sectional area of our "Cloaca Maxima" filled with putrid mud, over the top of which a little stream of gas-bubbling sewage was dribbling along; that is, they found the boasted "Cloaca Maxima" to be nothing more than a putrid mud trough with a trickle of sewage passing through it.

Having digested this fact, they bethought themselves of trying what would happen if this trickle of sewage were passed through a small glazed earthenware pipe.

Pursuing this inquiry in a methodical and practical manner, a length of such small earthenware pipe was laid down, and the "Cloaca Maxima" quantity of the sewage was poured down its throat, and to everybody's astonishment the little "earthenware pipe" accomplished not only all that "Cloaca Maxima" dicl, but even more-for it not only freely discharged the whole of the sewage passed into it, but left no festering sediment behind in the pipe.

Here was a great fact established, namely, that a small glazed earthenware pipe, laid at the same gradient as "Cloaca Iaxima," could not only discharge all the sewage usually passed by its big brother, but was, in adrlition, "self-clennsing" - that is to say, it not only left no sedimentitious matter in it, but removed any extrineous matter purposely placed therein.

Now began the battle between the "Cloaca Maxima" principle and what in derision was termed the "pot-drain," and a right royal battle it was.

Architects, engineers, and builders were at first almost universally on the side of "Cloaca Maxima," whilst "pot drain" was supported by Sir Edwin Chadwick, backed only by stubborn facts.

However, after a hard strugrgle little " pot drain" gained so complete a victory over "Cloaca Maxima" that even its greatest derotees were eventually obliged to discard it as both a costly and dangerous specimen of antiquity.

This is the early history of our present system of sewage removal by water carriage, and so complete has been the revolt from the "Cloaca Maxima" principle, that I may mention as an 
instance of its discomfiture, I have for several years past, without stoppage or inconvenience, been passing by gravitation, up hill and down dale, the whole of the sewage of Dudley, a town in this county, containing nearly 30,000 inhabitants, through a pipe five miles in length and only 13 inclies internal diameter.

\section{Sewage Disposal.}

It was soon found that the more perfect system of "pot pipe" drainage brought down to the outfalls not only a larger quantity of sewage than came down under the old system, but that the sewage was of a much more concentrated description.

The reasons for this were that under the "pot" system there was much less leakage into the subsoil, there were no sedimentary retentions, and there was a much more detailed collection than under the old "Cloaca Maxima" system, and these circumstances combined to give great urgency to the question as to what was to be done with the sewage on its discharge from the outfalls; and I remember the great battles which have raged, and which in fact are now raging, about the vexed question of sewage disposal.

The chemists were good enough to make the first attack upon the solution of this question, and dazzled our imaginations with "el dorado" calculations as to the manurial value of sewage deposit, when dried and manipulated according to their respective nostrums, so that the impression began to gan ground that all municipal rates and taxes would eventually be paid, and something over, out of the sewage-discharge of the urban localities.

Great, therefore, was the chagrin and disappointment when sewage manure company after sewage manure company had to be wound up, with assets consisting only of old bricks and mortar hardly sufficient in value to cover the auctioncer's expenses of their sale.

Then came the age of sewage farms and broad irrigation, and a large number of the leading municipal bodies purchased extensive tracts of farming land upon which to dispose of the sewage, and they thus acquired a sympathy with the great agricultural interests of the country, of which they had had no previous experience.

I am sorry to say that the experience these bodies thus acquired introduced them to those aspects of the agricultural question which are charged with originating the habit of "grumbling."

After the first few years everything appeared to be against sewage farms. 
In manufacturing towns the farming operations had to be conducted with sewage largely mixed with corrosive acids, upon which acids it was found that neither cabbages nor rye grass would thrive. Actions were being prosecuted on all sides for damages for the pollution of the streams into which the effluent was discharged-as at certain times and seasons neither the land nor the verretation could take up the whole of the effluent-some part of which had to be discharged raw into the streams.

In other cases actions were commenced to put a stop to the nuisance occasioned by noisome smells emanating from the farms and poisoning the atmosphere for long distances round. The farms were all found to be on too small a scale, and became "sewage sick," and addlitional land had then to be purchased at much more than ordinary agricultural value; and to cap all, the annual balances were almost universally on the wrong side.

After a few years' experience it was also found that raw sewage, containing all the sediment that was previously deposited in the old elongated cess-pools, was of a very clogging nature, and that in a short time it completely stopped all aêration to the roots of the plants; and that it was, therefore, difficult for them to thrive so well as in natural soils.

Various devices were adopted to overcome this last named evil, such as "intermittent downward filtration," by which system during one day the roots of the plants received a dose of sewage, and the next a dose of air.

These devices were adopted with varying degrees of success, but on the whole they failed to fully cure the evil; and at last it occurred to someone to try to precipitate the matters held in suspension out of the sewage, and only to run the clear effluent over the land.

In the first instance mere sludge tanks were adopted, with rough strainers, through which the sewage flowed at a slow rate so as to allow of the heavier matters being deposited in them, but these arrangements were found to be insufficient.

Lime and chemicals were afterwards added, which greatly aided the precipitation in the tanks, and another great stride was made by the adoption of "quiescent," instead of what were termed "flowing tanks," with a marked improvement in the effluent.

Under the quiescent system originated by the late Mr. James Lomax, of Bolton, the sewage when mixed with the chemicals was allowed a period of perfect rest in the tanks, and thereby the action of the chemicals became more rapid and effective. A further imirovement was also effected by drawing off the effluent periodically from the upper portion of the water in the tanks. 
The effluent when passed direct into streams from these precipitating tanks was however found, if alkaline, to set up a secondary fermentation, to prevent which the eflluent water was passed over a small area of land, and the sludge was utilised as a sort of top dressing to surrounding land, or taken away by farmers as back loading.

The plan last described is that now generally being adopted, and all those interested in the question of effluents are turning their attention to the discovery of some cheap precipitant that shall render the effluent from the precipitating tanks clear and bright, perfectly innocuous to fish life, good as an irrigator when so required, and incapable of secondary fermentation. I think it not improbable that some such material, or combination of materials, may be found before long; in fact, some people are under the impression that it is already discovered, and, if so, then, with sufficient land for precipitating tanks and sludge deposit, we may congratulate ourselves that the sewage difficulty has become a thing of the past,- - except in regard to a little item which, I fear, must always be present, and that is "annual cost."

The above is a sketch in outline only of the sewage disposal struggrles of the last 40 years, so far as they relate to water carried sewage.

The sketch is necessarily devoid of detail, and it has only been possible to give the more salient features of the retrospect.

Much has still to be done before we can say we have approached perfection; but as every successful effort means thousands of lives either saved or prolonged, we all can only wish God speed to all patient and faithful workers in this department of sanitation, whether their efforts are directed to perfecting the "water carried" or any other system of "sewage treatment and removal."

Very great progress has been made during the past forty years in the details of the fittings for house drainage; and, as our successive exhibitions show, every year is adding to the perfection of domestic sanitary appliances.

They are, in fact, now so perfect, that there is no reason why every house in the kingdom should not be fitted with apparatus which would place it beyond suspicion of any want of proper sanitation; and I am glad to learn that, under voluntary examining associations, even the much-abused plumber is becoming an intelligent and skilled graduate in sanitation.

With some bright exceptions, the improvements in the sanitary conditions of our villages have, unfortunately, not kept pace with those connected with domestic drainage appliances, 
nor with those in urban districts; but the medical officers of the rural authorities are fully alive to the sanitary defects of their districts, and are doing good work in continually pointing them out; and I am hopeful that the large sanitary powers now at the command of County Councils will be put in force with advantage in those districts, and that in the course of a few years good results will follow.

In the report of the Sanitary Committee to the County Council of the County of Worcester, clated May 18th, 1889, and signed by Sir Douglas Galton as chairman, the following are set out as provisions of the Local Government Act, 1888, having reference to the powers, duties, and liabilities of the Council with respect to matters, bearing on Sanitation, namely :

(a) The appointment, removal, and determination of the Salary of the Public Analyst [L.G. Act, $\$ 3(\mathrm{x})$ ].

(b) Rivers Pollution Prevention Act, 1876

$$
\text { [L.G. Act, } \S 14] \text {. }
$$

(c) The making of Bye Laws for prevention and suppression of Nuisances [L.G. Act, $\$ 16$ ].

(d) The appointment of a Medical Officer of Health

$$
\text { [L.G. Act, } \S \S 17,18 \text { and 19]. }
$$

(e) Payments in substitution for annual local grants [L.G. Act, § 24], namely :

(i.) To the Guardians of Unions for payments to Public Vaccinators [L.G. Act, $\$ 24$ (2) (a)].

(ii.) To the Local Authorities, one-half of the Salary of the Medical Officers of Health and Inspectors of Nuisances [L.G. Act, $\S 24(2)$ (c)].

(iii.) To the Guardians of Unions towards the remuneration of the Registrars of Births and Deaths

[L.G. Act, $\S 24(2)(\mathrm{d})]$.

(iv.) In respect of the maintenance of Pauper Lunatics [L.G. Act, $\$ 24$ (2) (e) (f) (g.)].

In accordance with these powers the Sanitury Committee, presided over by Sir Douglas Galton, recommended that a legally qualified Medical Officer of Health should be appointed for the county, who, under the control of the Sanitary Committee, should have a general supervision of all sanitary matters arising in the county, and who should not hold any other appointment nor engage in private practice.

The report also recommended as important that immediate steps should be taken to enforce "The Rivers Pollution Prevention Act, 1876," in relation to the streams within the jurisdiction of the Council, and that the several County Councils in the water-shed of the Severn should be requested to concur 
in a representation to the Local Gorernment Board to constitute a joint committee for that purpose.

By clause 19 of " The Local Government Act, 1888," every District Medical Officer is bound to send to the County Council a copy of any periodical report which he is now required to send to the Local Gorernment Board; and in the event of its being found, from any such report, that "The Public Health Act, 1875 ," is not being properly enforced in the district, or that any other matter affecting the public health of the district requires to be remedied, the County Council may cause a representation to be made to the Local Government Board on the matter.

Under this clause the eyes of the County Council, as regards sanitary matters, will be everywhere, with a statutory authority, by means of a representation, to call to its aid all the resources of the Local Government Board to remedy any sanitary defect.

By these clauses the County Council is now made an important unit of centralization with regard to all sanitary matters arising within the county, and consequently a much closer and more detailed investigation into sanitary evils is likely to be attained than was possible under the old system, in which the Local Govermment Board was practically the only centralized authority.

\section{WATER SUPPLy.}

With your kind permission we will now turn for a few minutes from the somewhat odorous subject of sewage to the sweeter one of water suplly, though on looking back I can remember the time when some towns in England were supplied with a mixture very little better than raw sewage, and certainly inferior to some of the clarified and purified eftluents of modern times.

At one time, within my memory, a large portion of the metropolis was supplied direct from the lower reaches of the Thames, between Battersea and Vauxhall bridges, with a liquid which at times could only be described as "unadulterated cholera mixture ;" and I remember, as a young engineer, going to sce a large Cornish pumping engine, just then erected by one of the London water companies for supplying its district with water pumped direct from the Thames, at a spot not more than half a mile below where, what was then termed the Ranelagh sewer, which drained Chelsea and other denselypopulated parts of London, emptied itself into the river on the opposite side from the engine.

Public opinion, aided by the outbreaks of cholera, and the 
fear of renewed attacks of that scourge,-with respect to which a glimmering notion was dawning upon the public mind that these attacks of cholera hal some connection with the want of proper sanitation, - torgether with the continual bombardments by the Board of Health, ably directed by Sir Edwin Chadwick and his medical staff on all such abominations as unfiltered-between bridge Thames water supply-gradually brought about a hetter state of things, which in some cases had already been effected in the provinces, and the example set by which, London was urged to follow, namely :-

(1) To avoid originally contaminated sources of water supply.

(2) To filter all supplies derived from surface sources.

(3) To give a constiunt supply.

In accordance with the first named requisition, the intakes of the Metropolitan Companies were removed higher up the river, beyond the reach of contamination from the London sewage.

The filtration of river water was gradually introduced, but so little was then known of the now common art and mystery of filtration on a large scale, that we had to go to some small works supplying a town in Scotland for our first practical experience on this subject, and the little sand filter there, only a few square yards in extent, is the parent of all the filter beds, upwards of 100 acres in extent, through which the $150,000,000$ gallons of river water daily required for the supply of London are filtered, in addition to innumerable filter beds connected with provincial water works.

There was not mucl controversy about the question of filtration, as its merits were soon appreciated; but a very great fight raged for a considerable periorl about the question of constant supply.

From time immemorial the supplies given by water companies, with very few exceptions, were, in what was termed "the intermittent system," that is, the water was turned on for an hour or two a day only for each particular street.

The supply of water for the 24 hours had consequently to be caught and stored in tanks, butts, or tubs, or other sucli receptacles, in which, if originally pure, it frequently became foul and contaminated with surrounding abominations.

This intermittent system involved not only great inconvenience to the consumers, but, from the circumstances above namerl, was the cause of a large amount of illness; and again the Board of Health, directed by Sir Edwin Chadwick, came to the front and dealt some heavy blows at this antiquated and inconvenient system. 
At the time when this controversy first broke out, I happened to be a pupil of one of the leading Metropolitan Water Engineers, who unfortunately held very strong opinions adverse to the system of constant supply, and he upheld the system of "intermittent" supply as perfection. In fact, he went so far as to say that the constant supply system on a large scale was "impossible," and he wrote a pamphlet to prove it, and for any one in his office to hold the shadow of an opinion in favour of the "constant supply" system was, as you may easily suppose, "flat treason."

In reply to this pamphlet, Sir Edwin Chadwick showed that so far from the constant supply system being the impossible theory it was represented to be by the engineer who was so strong a supporter of the intermittent system, it had actually been long in operation on a large scale in Nottingham, the water works in which town were under the able management of a rising young engineer named Hawksley-whose name, as that of a sound and practical engineer has since become of world wide reputation, and of whose works the Faithful City in which we are now assembled has some good examples, and will probably have more.

Amongst the water works originally constructed by the enginecr who so strongly advocated the intermittent system, whilst I was a pupil of his, were those at Wolverhampton, in the alloining county.

These works were constructed on the very strictest principles as a "model intermittent supply" water works, and it became my lot not only to superintend their construction, but to have the management of them placed in my hands after their completion.

For two years I struggled on with the intermittent system, but could make very little progress, as the fittings connected with that system were expensive, and consequently deterred people from having a supply from the water works, and altogether the inconveniences were such as not to encourage domestic consumption.

Under these circumstances, with the sanction of the directors, I made the necessary alterations in the works-which were not of an expensive character-and we commenced giving the supply on the " constant system" in the year 1849 , or just forty years ago, since which time the works, which have passed into the lands of the municipal authority, have grown and extended until now they are supplying 120,000 persons on the constant system, and have a revenue of $£ 23,000$ a-year-that is to say, an annual revenue nearly equal to the capital originally embarked in the undertaking. 
The conversion of the Wolverhampton works from "intermittent" to "constant" supply happened to come to the knowlerlge of Sir Edwin Cliadwick through Sir Robert Rawlinson, then one of the engincering inspectors under the Board of Health, and I was requested to make some experiments as to the hourly consumption in Wolverhampton under the constant system.

These experiments showed that instead of having to provide pipes of a magnitude sufficient to afford a supply of water to every customer at the same time (as had been argued by the upholders of the intermittent system) they need not be larger than sufficient to supply the whole consumption of the twentyfour hours in about nine hours, and in fact that the distribution pipes might be made with safety somewhat smaller than had been the practice under the "intermittent" system.

These facts were brought out in evidence which I gave before the Board of Health in 1850, and also shortly afterwards before a Parliamentary Committce on Metropolitan Water Supply which was presiderl over by the late Sir James Graham.

The evidence given before this latter Committee settled the question as to the feasibility and advantage of the "constant supply" system, and there has since been no controversy worthy of the name in favour of the "intermittent system."

I should also remark that whilst forty years since it was stated to be an impossibility to give a constant supply on a large scale, now nearly $3 \frac{1}{4}$ out of the $5 \frac{1}{2}$ million of inliabitants within the limits of supply of the Metropolitan Water Companies are enjoying the alvantage of a supply on that system, whilst in the provincial water works it is almost universally adopted.

\section{The Severn.}

Before leaving the subject of water supply, I should like to be allowed to touch upon a question a little nearer home.

Yon will all be aware that the city of Worcester is situate on the banks of a magnificent river named the Severn, which has its origin far up in the Welsh mountains, and which after flowing thence through Shrewsbury, Bridgnorth, this city, Tewkesbury, and Gloucester, empties itself into the Bristol Clamnel. And if before coming to the sanitary points which I wish to bring out, you will allow me to cligress for a moment, I may remark that this river can boast of hilving had the first iron boat float upon its fair bosom, and of having been spanned by the first iron bridgre ever constructed, a bridge which is still in existence, and which has given its name to an extensive district in Shropshire. 
Within the last forty ycars a considerable length of the river has been redeemed from a state of mature, and has been canalised, under Parliamentary powers granted to the Severn Commissioners, by the construction of locks and weirs between Gloucester and Stourport, a distance of about forty-two miles, and by means of which improvements, goods and merchandise to the extent of about a thousand tons a clay are now carried upon it by vessels of from 30 to 150 tons burden.

The spirit of enterprise is, however, not yet satisfied with this achievement, and further improvements are in contemplation, having for their object the provision of a sufficient navigable depth to enable sea-going steamers of from 300 to 400 tons burden to navigate the river up to the Quays in this city, that is to say, to within 30 miles of the very lieart and centre of England.

From an investigation which I have recently been called upon to make as Engineer to the Severn Commissioners, I find that the cost of this creat inland navigation improvement will be comparatively small, and I trust that most of us may live to see the day when vessels of this description may be found daily plying between Worcester and foreign ports, and so that, practically, Worcester may become the sea port for the great manufacturing interests which have their seats in this and the adjoining county of Stafford.

Let this suffice for the little digression for which $\mathrm{I}$ craved your indulgence.

I mentioned just now that the Severn has its origin in the far-off Welsh mountains, upon which the annual rainfall is very heary; and some eight or ten years since the Corporation of Liverpool, casting about for an increased supply of water for their city and its numcrous dependencies, bethought themselves of these Welsh hills, the rainfall on which supplies a large moportion of the water passing down the Severn, and they applied to Parliament for power to construct a large collecting reservoir on an upland tributary of the river named the "Vy'nwy."

The reservoir was intended to be on a large scale, that is to say, it was intended to have an area of over 1,100 acres, a depth of more than 70 feet in some parts, and to hold 13,000 million gallons of water.

The drainage areas or collecting grounds proposed to be appropriated extended over 23,000 acres, and represented about one-ninth of the whole upland range of Welsh hills, whence, as before stated, the larger proportion of the water supplying the Severn is derived, and whence comes by far the largest proportion of pure water passing down it. 
In the erent of such contemplated works being carried out it became important therefore, not only per se, but as a matter of precedent also, that the Severn interests, especially in their sanitary aspects, should be protected by its being made compulsory on the Corporation of Liverpool to deliver an alequate supply of compensation water into the river from the intended rescrvoir.

I am happy to say that Parliament took this view, and the compensation to be given from the one-ninth of the Welsh Hill water-shed appropriated to Liverpool, is on such a scale that in the event of the other eight-ninths being hereafter appropriated for the sanitary requirements of the metropolis (which has given indications of lonking in this direction,) or any other places, there will at all times be at least 100 million gallons of pure Welsh Hill water passing each day under Worcester Bridge, and at times a much larger quantity.

The basis upon which the delivery of this compensation water was settled is somewhat peculiar, and it may therefore be mentioned here possilly with advantage.

There is in the first place a uniform and constant discharge of ten million gallons a day from the reservoir into the river, and in the second place an additional discharere of forty million gallons a clay for four days in each of the eirlit months between the last day of February and the first day of November in each year.

The reservoir is now practically completed, and the water was commenced to be impounded in it on the 28 th November, 1888 , since which date the statutory quantities of daily and monthly compensation water have been regularly discharged from it.

The reservoir is now filled to within between eight and nine feet from top water line or overflow level, and after having duly provided for the compensation water discharged into the river, amounting to over 4,000,000,000 grallons from the date named, there remains for the use of Liverpool about $11,000,000,000$ gallons within the reservoir.

I look upon these flushes of pure Welsh Hill water during the summer months as a valuable sanitary advantage to the river, and it is for this reason that $I$ lave mentioned them.

These flushes also being in the nature of small freshets, are of great advantage to the fish life in the river, and especially to the salmon, in connection with which fish the Severn now takes first rank in quantity as it has long clone in quality, and the interests in connection with which are worth over $£ 20,(100$ a year.

Whilst still on the subject, I should state that daily records 
of the height of the water in the river, of the direction of the wind, and of the temperature of the air and of the water in the river, are being and have been taken during the past three years; and as time passes on, they will form a valuable record for comparative purposes.

These particulars are recorded at various stations extending from Portishead, on the Bristol Avon, to the Reservoir on the River Vyrnwy, a distance of 200 miles measured along the river, and they are collated annually, and printed for public information, by the Severn Fishery Board.

Some interesting facts are being brought to light by these records, one particularly for which I was not prepared, namely, that, except under some special circumstances, the temperature of the water in the river is higher than that of the air, a fact which opens up several questions of scientific interest.

\section{Building Materials, \&c.}

Having already detained you too long on the matters to which I have ventured to refer, I will leave it to others, more competent to do so, to deal with the architectural portion of the subjects referred to in this section. The question of the architectural progress of the past forty years forms too wide a ficld for me to do so in this address. I will only remark that it has undoubtedly been very great, especially in regard to the dwellings of the poorer classes.

This improvement has been greatly encouraged by the removal of the duties on building materials which has taken place during tliat period.

Good drainage and pure water supply were then quite the exception for this class of house, and who can picture to himself the discomfort, disease, and premature deaths which the absence of these requisites caused in the houses of the working classes -a large proportion of which were constructed without back doors or windows, and without any means of through ventilation?

Now in many cases we not only see the comfort and health due to good dianage and good water supply, with better ventilation and larger spaces, consequent on better and cheaper building materials, but, in addition, some not unsuccessful attempts at ornamentation.

With respect to this latter point, I should remark that it has taken nearly a whole generation to get rid of the art-depressing influence of the exciseman in the brickfield, and we are now only beginning to realise the ornamental capacities of our brickearths when properly blended, moulded, and burnt. 
The advent of the exciseman reduced the tasteful artist in brick-earth of Queen Anne's time to the status of the unartistic manufacturer of common "stocks," 9 inches by 3 inches by $4 \frac{1}{2}$ inches, and who gradually descended into a low class of "artful dodger," the highest ambition of whose life appeared to be to outwit the representative of the Excise Law.

We should be thankful that we live in times which have enabled us to dispense with taxes on building materials and on the windows which let light and air into our dwellings, and in which we are freed from the hateful presence of the exciseman in the brickfield. Art cannot exist where he is Lord paramount, nor under such peremptory codes as the stringent regulations of my Lords of the Board of Customs.

I have now dwelt upon some of the improvements in sanitary matters of the last forty years-but how much has yet to be accomplished !

How is it that in almost every newspaper we open we find accounts of outbreaks in some place or other of typhoid or scarlet fever, or some other ailment preventable by proper sanitary arrangement?

How is it that our death-rate still shows so high a range of mortality, especially amongst the young children of the poorer classes?

One could go on with a string of such inquiries ad nausenm, but I will not weary you, except to say that the work of sanitation still remaining to be done is of colossal proportions.

All honour, therefore, to those who without hope of reward devote their skilled intelligence to the improvement of the sanitary state of their surroundings, for in more senses than one sucll people are "the salt of the earth!"

\section{Smoke Abatement.}

Before concluding this address I wish, with your permission, to call attention to one subject in which during the past forty years we appear not only to have made no improvement, but in respect of which we appear, to some extent by force of circumstances, to have lamentably receded.

I refer to the non-consumption of the smoke made by our domestic fires.

The awful example in this respect is, of course, London, the grimy smoke of which, issuing from 600,000 to 700,000 kitchen chimneys, turns day, in certain states of the atmosphere, into midnight darkness-in fact, into more than midnight darkness, for in ordinary midnight darkness we can generally manage to 
see a few stars overhead, whilst in the darkness created by the smoke from the domestic chimney we can only painfully grope our way from one faintly glimmering gas light to another, whilst overhead everything is cimmerian.

There have been great heart searchings with respect to this evil, and many suggestions have been made as to its cure, but, hitherto, without success, as we are still the slaves of the "blacks," which blind our eyes, which fill our nostrils and lungs, which dirty our clothes, which duplicate our death-rate during their distressing presence, and which, like the plague of frogs in Erypt, enter our chambers and profusely decorate our beds and furniture with their loathesome digits, and which finally, with their sulphureous impregnations, reduce all our books and papers to a mummy-like condition.

I find from the return of coal, culm, and cinders published by the authority of the Corporation of London, that the quantity of these materials brought into the London district by railway, canal, and sea during the year 1888 was $12,533,088$ tons; and deducting the quantity shipped coastwise and exported from the Port of London during that time, which, according to a return obligingly furnished to me by the Board of Customs, amounted to 273,134 tons - and making a large allowance for bunker coal and coal consumed in the outlying districts of the metropolis-I consider the consumption proper to London is certainly not less than $11,(100,000$ tons a year, that is about 30,000 tons a day on the average. This is rather more than the whole annual produce and consumption of the South Staffordshire and East Worcestershire Mining Districts, lnown: emphatically, as the "black country."

In the year 1884 the quantity delivered into the Londor district was $11,140,576$ tons, as against $12,533,088$ tons delivered last year. This shows an increase in the quinquennia period, 1884-1888, of $1,393,512$ tons, or an increase at the rate of 278,702 tons per annum during that period.

Probably one-tlird of the total estimated annual consumptior of 11,000,000 tons takes place in manufactories, which, by law are bound to consume their own smoke, and in which that operation is to some extent accomplished; but fully $20,00 \mathrm{C}$ tons a day on the average will be piled on the domestic fire the smoke from which is still a legalised nuisance.

During the four winter months in the year, the domestic consumption will probably reach 30,000 tons a day, and witl the ever-increasing number of domestic chimneys within the metropolitan area-estimated at about 15,000 a-year-thi consumption of fuel must also erer be an increasing quantity.

To give some idea of the size of the coal-scuttle necessary t 
provide for one day's consumption of coal in the domestic grates of London, it would, in winter time, have to be large enough to hold a lump of coal one acre in area, that is about 300 feet long, 150 feet broad, and 30 feet thick; and it is a lump of coal of that magnitude which, in winter time, is daily reduced in the metropolitan domestic grate to ashes and-smoke, and alding the consumption in manufactories, the block would have to be of the same length and breadth but 40 fect thick.

I have not seen any calculation of the numbers of cube miles of smoky atmosphere which would be produced by the combustion of such a lump of coal, but you can easily understand that it would be very great, and that in a still and fougry atmosphere the volume would be concentrated in the disagreeable manner which ends in dense darkness.

Possibly as electricity gradually takes the place of as as our domestic luminant, the Gas Companies may more than heretofore turn their attention, as sugrgested by the late Sir William Siemens, to the production of heating gas; and this description of gas, which is of great calorific, but little illuminating power, may take the place of the domestic coal-scuttle, and so bring the production of smoke more under control.

There are, however, dangers to be guarded against, even should the time come when, by such a gas, the domestic coal-scuttle and all its disagreéable contingencies have been banished.

The principle one arises from the fact that the products of combustion evolved by the burning of such gas are only capable of floating in the atmosphere wlien heated to a tomperature of $300^{\circ}$ Fahrenheit, and, consequently, the moment they leave the chimney tops they begin to cool, and so, falling below the temperature of equilibrium, they would sink to the ground in still air; and thus, whilst we might escape the Scyllit of being suffocated by smuts, we might not be able to escape the Charybdis of being poisoned by carbonic acid gas descending into the narrow streets, courts, and alleys of the metropolis.

The question is full of difficulties and still awaits solution.

The Smoke Abatement Institution has done good service in collecting information on the subject, and in testing various appliances; and the interest of inventive genius in the question is so great, that during the past 10 years three patents relating to it have, on the average, been taken out for every two working days during that time.

I have no suggestion to make for dealing in detail with this question, which is daily becoming more and more urgent, not only with respect to London, but with respect also to many of our larger towns, where great numbers of domestic chimneys 
are congregated around and amongst coal burning works and factories.

I anticipate, however, that before long the evil will become so intolerable, that it will be dealt with in a very summary manner, by bringing the smoke issuing from the domestic chimney under the same regulations as those for smoke issuing from factory stacks, and until this is done, I doubt whether the individual householder can be brought to attack the question in the only way likely to bring about results on a scale beneficial to the community at large.

\section{Concldoing Remarks.}

I have now only to apologise for having detained you so long, and to thank you for the attention with which you have favoured me.

We have travelled together along the border lands of the many subjects touched upon in this address-principally engaged in taking retrospective views-though occasionally looking around upon the subjects which are exciting the interest of sanitarians to-day, and now and then taking a not unhopef ul peep into the future, which, judging from the diligent and intelligent workers who are now entering the arena, will, I anticipate, be of a much more rapid and brilliant character as regards sanitary progress, than it has been for those who must soon leave it,.although the struggles of those who have laid deep and solidly the foundations of sanitary science and practice will always be worthy to be held in honourable remembrance, however brilliant the careers of their successors may be.

The President (Mr. G. W. Hastrngs) moved a vote of thanks to Mr. Marten for his most instructive and interesting address. Mr. Marten had alluded, from his own experience and knowledge, to the effect produced on the health of a population by fen drainage; and he was sure they would allow him (the speaker) to refer to a stutement that was made by his father, Sir Charles Hastings, now twenty-five years ago, on the effect which had been produced on disease in the county of Worcester by the enclosure and, consequently, the drainage of land. Sir Charles Hastings showed from the records of the Worcester Infirmary that down to the beginning of the present century ague was the predominant disease, and that the books of the Infirmary were full of records of such cases; but from the time when the great enclosures in Worcestershire took place, such as the enclosure, for instance, of a great part of Malveru Chase, when the land, though it 
was not deep drained, was thrown into furrows for cultivation and ditches were dig, and the surface water carried away, the records of the Infirmary ceased to show cases of ague. Now, if Mr. Marten would allow him, he would give one example from his own experience of the prevalence of "Cloaca Maxima" in houses no very long time ago. Some few years since, he resolved, as Chairman of the House Committee of the Quarter Sessions, to have a thorough investigation of the Shire-hall, which was within the bounds, though not within the jurisdiction, of the city of Worcester. He found that the sanitary condition of the building, as he had strongly suspected, was this: the only drain out of the house was a very large brick drain under the hall, which discharged into a cesspool under the drive just in front of the house, which cesspool had never been approached after its formation for a period of furty years. There was no other outlet of any kind, and there was not a single convenience in the place which had any pipe into the open air. He had the drain, the bricks of which were saturated with sewage matter, filled up and thoroughly deodorised, and a drain of humble little glared pipes, such as Mr. Marten had spoken of, was constructed on each side of the house outside, with ventilating shafts, carried to the top of the roof in every instance. Since that time the Shire-hall had been a thoroughly sanitary building. He was glad to hear Mr. Marten's remarks about the importance of plumbers' work in sinitary matters. He was also glad to hear that there were no small number of plumbers who had obtilined certificates from the Sanitary Institute attending the meeting in Worcester, thus showing that they were not only willing to go to the Institute to perfect their knowledge and to obtain certificates, but that they felt an abiding interest in its work. There was one expression in Mr. Marten's address from which be must talie leave to differ on a matter of fact. Mr. Marten spoke of the large sanitary powers that had been given to County Councils. He (the spealier) would be very glad to be told what they were, for as Chairman of the County Council of Worcestershire, he was maturally most desirous that it should in every respect fulfil its duties; but beyond some small matters, he was not aware of any function which it was possible for the County Council to fultil under the present Act so far as sanitary matters were concerned, with the exception of course of their River Pollution powers. The County Council could, and he hoped would, appoint a Medical Officer of Health : but unless the other sanitary authorities of the county joined in giving him powers, the officer's functions would be necessarily confined to obtaining information and reporting, and he would be unable to do any really active sanitary work of any description. The County Comicil had powers of enquiry and slight powers of supervision, but they had no power to do sanitary work themselves; and he could only hope that Mr. Marten spoke in the character of a prophet as to the legislation that would come in future years, as the experience of Parliament grew, and as they discovered (as he hoped they would discover) that wide powers were necessary for efficient administration in these matters, that it was not the swall bodies to whom they could as a rule protit- 
ably entrust the health of the population of this country. With regard to the County Council of Worcestershire, if Parliament would only entrust them with some of those large sanitary powers of which Mr. Marten had spoken, he would undertake to say that they would be at once promptly used by the Council. Some people seemed to regard the Institute and its meetings as a means which individuals used solely for the purpose of ventilating their fads. How far this might be so he was not in a position to discuss. He could only say that all he had beard at the Congress seemed to be of a most practical kind. If indeed it was thought a fad to desire that their fellow creatures should enjoy good health, that they should be free from disease, that they should attain to a good longevity, then he admitted that the Institute was certainly productive of fads. From what he had seen and heard, he believed the Institute was carrying out a noble object in spreading among people of this country in every place that it visited sound practical knowledge on sanitary matters, and in instilling into them a high ambition to emulate all that had been well done in sanitary science, and to apply it to their own administration and to their own homes.

\section{On "Sewage Disposal," by Prof. Henry Robinson, M.Inst.C.E., F.G.S., F.S.I.}

THE subject of "Sewage Disposal," which I have been desired ly the Council to bring before this Congress, may with advantage be regarded from two points of view, namely, one which immediately concerns the individual householder and his family, and, secondly, that which affects the community.

As one of the objects of these Congresses is to impress upon the public mind the necessity for attending to well known sanitary rules as regards house sanitation, I would at the outset say a few words in this direction, knowing as I do how requisite it is to repeat the simplest truths to ensure their being acted upon.

I have no hesitation in stating my opinion that only a very small proportion of the dwellings of the upper and middle classes throughout the country are free from dangers to health, uwing to the indifference or neglect of the occupiers to ascertain whether the essentials to making a house healthy have been complied with. This opinion I hold both with reference to houses in the Metropolis and other large towns, and also with reference to mansions and detached residences in the country.

Places of health resort are visited by those who seek a brief rest to recruit their worn out energies, and who occupy louses about whose previous sanitary history no informa- 